\title{
AURICULAR CONFESSION: THE CELTIC GIFT TO THE CHURCH
}

\author{
PETER TYLER* \\ St Mary's University
}

\begin{abstract}
This article traces the evolution of auricular confession from its origins in the spiritual diakresis in the early desert tradition and argues that through the Celtic churches of Northern Europe the practice is introduced into the Western Church culminating in the decrees of the Fourth Lateran Council in 1215. By developing the desert tradition of diakresis it will be argued that the Celtic system triumphed because of its stronger psychological verisimilitude compared to the Southern Mediterranean traditions of public one-off penance.
\end{abstract}

KEY WORDS: penance, confession celtic, church, auricular

\section{Penance in the Early Church}

This article will argue that confession emerged in early Christianity as a melding of two practices. On the one hand, there was the desert tradition of spiritual direction with its family resemblance to our contemporary $21 \mathrm{st}$ century psychological schools-especially with its 'hermeneutic of suspicion' with regards to individual motivation and the stress placed on the need for all those who seek God to undertake the search in the company of another seeker. On the other hand, we see an acknowledgement of the unique locus of confession as the place where we can establish a relationship to the transcendent in our lives. From these two sources confession, will thus slowly become the sacramental act that we recognise today in the Catholic Church where the transcendent encounters the immanent. Accordingly, the article will suggest arguments for why this occurred and the events surrounding the 13th century when the sacrament was codified within the canons of the Catholic Church.

In the Catholic context, the power of the Church to exercise the forgiveness of $\sin$ in response to the penitential act of the believer is traced

* PETER TYLER (PhD 2000, University of Durham, United Kingdom) is Professor of Pastoral Theology and Spirituality at St Mary's University, Twickenham, United Kingdom.Email: peter.tyler@stmarys.ac.uk. 
back to Christ's exhortation to Peter and the apostles 'to bind or loose' what is on earth as in heaven (Matthew 16:19) reiterated in numerous sayings such as the exhortation not to forgive seven times but 'seventy times seven times' (Matthew 18:22). As Karl Rahner points out (1969: 389), the preexisting Jewish communities whence early Christianity arose would have been familiar with the practice of excommunication or expulsion from the synagogue for grave sins. The Rules of the Qumram Community, for example, stipulate such penances for acts such as lying, obstinacy, impatience, blasphemy, anger, and even 'guffawing foolishly' (for which the punishment is 30 days penance) (The Rule of Community $1 \mathrm{QS}, \mathrm{VI}, 25-\mathrm{VII}, 25)$. The early church took seriously this notion of the communal nature of guilt and sin and the power of the whole community to witness to the transgressions of the individual. Just as Christ displays 'the authority on earth to forgive sins' (Mark 2:10) so the church he founded took this authority on to itself, especially as manifest in its communal and ecclesial aspect as 'Body of Christ'. The passage in John 20:22-23 where the risen Christ breathes on the assembled disciples the Holy Spirit and instructs them that if you forgive the sins of any, they are forgiven them; if you retain the sins of any, they are retained' was interpreted as the moment this power was transferred to the early church. From these roots grew the practice that confession, penance and absolution would continue and vouchsafe the gift of the Holy Spirit to the believer as they entered the community of Christians at Baptism.

Early church writers such as in the author of the Shepherd of Hermas (second century), Tertullian (On Penitence), Clement of Alexandria (The Stromata), and Origen (Homilies on Leviticus) all stress that such a 'reconciliation' can only happen once in the Christian's life suggesting that the usual early Christian practice was to see confession as a once-only opportunity for reconciliation with God and the Church on earth. As Tertullian puts it:

(God) has permitted the door of forgiveness, although it is closed and locked by the bar of Baptism, still to stand somewhat open. He placed in the vestibule a second penitence so that it may open the door to those who knock; only once, however, because it is already a second time... it should also be in public not private (On Penitence 10).

However, this one-off reconciliation might apply to all sinners, even if their sins included heresy, schism or fornication. In this respect, Tertullian's comparison of confession to a plank thrown to a drowning man has perhaps become the most quoted metaphor developed at this period, used by $\mathrm{St} \mathrm{Au}-$ gustine and the Council of Trent alike:

Do thou, a sinner like myself-yes and a lesser one than I, for I recognise my eminence in evil-lay hold of it and grip it fast, as one who is shipwrecked holds 
on to a plank of salvation (ut naufragus alicuius tabulae fidem). It will buoy you up when you are plunged into a sea of sin and bear you safely to the harbour of divine mercy (On Penitence 40, c.f. 1 Timothy 1:19 and Plato, Phaedo 85d).

The ceremony attached to such confession and reconciliation with the body of the Church was often elaborate and very public, frequently involving the penitent wearing a distinctive dress, fasting and taking a particular part in the liturgy to finally receive the reconciliation of the church through the laying on of a Bishop's hands and the anointing of oil-often not until the end of one's life. Confession in this early church sense is thus very public, very ceremonial and very final. In Rahner's words, 'there is no trace of a “private” sacramental penance' (Rahner 1983: 11). In the West, these public shows of sacramental penance gradually become associated with the observances of Lent which begins with the public observance of the penitential rites by those who have sinned (Rahner 1969: 392). This is still attested by church ceremonies to mark the beginning of Lent to this day (such as the public distribution of ashes). This early form of public, one-off penance and confession thus persisted well into the late classical / early medieval period. The Synod of Toledo in 589 AD (Canon 11) still defends it but gradually it became to be seen as more necessary for those who had caused public shame and scandal to the Church. By the 5th and 6th centuries such public penances had largely become a one-off action in preparation for death. As Dallen puts it: 'since it could take place only once in a lifetime and since it often had consequences for the remainder of the penitents' lives, people's distaste was understandable' (Dallen 1991:76).

From the 6th century onwards, for reasons which commentators find hard to explain, in the Celtic lands of Britain and Ireland a new form of penance and confession arose. [Within a generation of Augustine's death, St Patrick will write an influential confessio, thus attesting to the early love of the form in the Celtic lands. I am indebted to Bernard McGinn to drawing this to my attention.] Various commentators have presented theories as to why from this period onwards individual personalised confession and absolution took hold amongst these peoples. As Dallen points out, however, there were significant differences between monastic confession as it arose in the British Isles during these early centuries and what would later be accepted by the Western Church at the Fourth Lateran Council as the universal practice of personal confession. Both held in common that there was a 'tariff' by which the 'amount of sin' could be measured out and penance given. However, the Celts had no ritual in their system to mark the penitent's return to grace within the church (Dallen 1991: 103). For Dallen, the Celts and Anglo-Saxons had 'a fear and anxiety regarding the supernatural' which 'expressed itself in a preoccupation with demons and fairies and the like' (Dallen 1991: 103). Which, to this (Celtic origin) reader at least, seems 
a bit far-fetched. A little more convincing, as Dallen concurs, is the suggestion of the influence of the desert tradition of spiritual direction on the practices and shape of the Celtic church. This will be the line of investigation followed in this article.

Accepting that the Celtic church was focussed largely upon monastic foundations and that the desert form of individual spiritual direction was prevalent there it is accordingly not so difficult to explain the origins of this form of confession as an outgrowth of spiritual direction as practised amongst these monastic communities. The clear links between the Celtic and Eastern churches, not least geographical through shared sea routes, and the ongoing tradition of the East to allow Christian leaders other than Bishops, in some cases lay-people and monks, to give forgiveness to sins (See Rahner 1969: 394), suggests that something of this Eastern spirit was clearly abroad in the Celtic church. This new Celtic form of forgiveness of sins, or absolution, was not confined to one specific occasion, or indeed one specific season such as Lent, and could be uttered by a priest or monk using a simple verbal formula (Rahner 1983:14). By the eighth century it is clear that this new form of 'private' confession with its accompanying tariff of penances had spread throughout the whole of Western Europe slowly replacing the more public penances of the older tradition. Accordingly, to understand the dynamic power of this practice and why it would have such an effect on the medieval church we should delve back into the desert roots of these forms of confession, or as the desert elders termed it, diakresis.

\section{Cassian and the Desert Fathers and Mothers}

From its beginnings, early Christianity places a premium on the use of $d i$ akresis or 'the discernment of spirits' which will be necessary to create that essential metanoia so central to its spiritual tradition. Time and again the early desert fathers and mothers exhort their followers to heed the advice of St Paul and to 'examine yourselves and test yourselves' (2 Corinthians 13:5, see The Life of St Anthony 55), noticing in particular that an apparently good action, deed or thought may have a harmful purpose or end. As we shall see, this call for 'self knowledge' will be a recurring theme throughout the Christian tradition of confession.

Thus, we find in the desert fathers and mothers a moral anthropology that exhorts us to redirect the passions away from the destructive and towards the constructive. However, they continually also remember the advice of the elders that this must not take place in too hard or harsh an environment that breaks the individual through excessive penance. As St Anthony explains in a famous passage:

A hunter in the desert saw Abba Anthony enjoying himself with the brethren and was shocked. Wanting to show him that it was necessary sometimes to meet the 
needs of the brethren, the old man said to him, 'Put an arrow in your bow and shoot it'. So he did. The old man then said, 'Shoot another', and he did so. Then the old man said, 'Shoot yet again', and the hunter replied: 'If I bend my bow so much I will break it.' Then the old man said to him, 'It is the same with the work of God. If we stretch the brethren beyond measure they will soon break' (Sayings of the Desert Fathers in Ward 1984: 13).

John Cassian, born in Dacia (present-day Romania) around the year 360 and who spent most of his adult life detailing the work and thought of the early desert elders, quotes with approval in his Conferences (2.16.1) the old Greek saying: 'extremes meet' and continues 'for the extreme of fasting comes to the same end as overeating does, and excessive prolongation of a vigil is as detrimental to a monk as the torpor of heavy sleep is'. The fathers and mothers wisely counsel that we must always examine our motives for everything we do, not least our pious and penitential acts. These, they counsel, are not above the action of the destructive and harmful forces within ourselves. The aim of the desert fathers and mothers is not to seek penance for penance's sake but to engage in ascesis or 'training' to enable us to come closer to God. For them, there is a clear distinction between this 'training' of desire and suppression or repression of desire, a theme we shall return to later. We could say that they engender a 'hermeneutic of suspicion' within the seeker-never trust your motives but always examine them.

Recognising the danger of self-deception the desert elders realised the importance of having a guide or at least someone to whom we can open up our consciences and thoughts. Indeed, Cassian in the Conferences sees this disclosure of thoughts as the most important element of the monk's life. 'Not only all our actions', he writes, 'but even all our thoughts should be offered to the inspection of the elders, so that, not trusting in one's own judgement, one may submit in every respect to their understanding' (Conferences 2.10.1). For, 'as soon as a wicked thought has been revealed it loses its power, and even before the judgement of discernment is exercised the loathsome serpent... departs as a kind of laughing stock and object of dishonour' (Conferences 2.10.1). As Freud and the early psychologists were to rediscover at the beginning of the 20th century, the act of telling a secret or desire can often kill its power over us. The art of confession in the desert tradition realised that the act of speaking holds its own power over the passions of the soul. In this way, spiritual direction and confession become a choreography between what is said and what is unsaid as the power of the utterance of the word cannot be denied and it is one of the main driving motivations behind the confessional urge-a key theme to which we shall return throughout this book.

To illustrate the importance of such disclosure of one's inmost thoughts to others Cassian tells the story of Abba Serapion whom he had come across 
during his travels in the deserts of North Africa and Asia Minor earlier in his life. The young Serapion, when living with the old Abba Theonas, having eaten the main meal of the day would often hide a biscuit under his cloak so that he could eat it later on in his own cell. One evening a group of seekers came to the old Abba to hear a conference on gluttony and disordered desire. So upset was Serapion by what he heard, and overcome with remorse, he threw the biscuit on to the floor and begged mercy and indulgence from the old Abba for his theft. The kindly old man, however, said to the boy: 'take heart, my boy. Your confession freed you from this captivity even before I spoke. Today you have triumphed over your conqueror and adversary, defeating him by your confession more decisively than you yourself had been overthrown by him because of your silence' (Conferences 2.11.4). No sooner had the Abba finished speaking than a sulphurous flame appeared from the young man's breast and left all in the room astonished as he wept for his sins.

Traditionally, then, the process of confession happened through two means, the disclosure of temptations and desires to another more experienced seeker, and the process of 'seeking a word' from a spiritual elder. Cassian is at pains to stress, however, that this discernment of spirits is not necessarily a gift of grey hairs and many years. The elderly are as much prone to deception as the young (Conferences 2.8.1). He gives numerous examples of this. The elder Heron who was revered by many disciples yet finally took his own life jumping down a well for a devil 'disguised as an angel of light' had tricked him into thinking God's angels would protect him as he jumped in the well and the miracle would bring many more to the faith. As Cassian states:

Just as all young men are not similarly fervent in spirit and instructed in discipline and the best habits, so neither in fact can all the elders be found to be similarly perfect and upright. For the riches of elders are not to be measured by their grey hairs but by the hard work of their youth and the deserts of their past labours (Conferences 2.13.1).

Once having carefully selected a guide Cassian counsels suspicion of motives. True discernment of spirits requires a hermeneutic of suspicion regarding the very nature of ourselves. Within this tradition, then, everything we experience must be explored with another, nothing should be left out of our account of the seeker to her fellow Christians:

Everything that is thought of is offered to the inspection of the elders, so that, not trusting one's own judgement, one may submit in every respect to their understanding and may know how to judge what is good and bad according to what they have handed down (Abba Moses in Cassian Conferences 2.10.1). 
This suspicion of motives goes alongside a deep humility in following the advice of the one to whom the seeker discloses their story. Just as a client seeking therapy today must trust the skill of the therapist and open themselves up to their judgement so we find the same relationship in the desert tradition.

Part of the practice of this humility in the disclosure to the elder is for the penitent to free themselves from the tyranny of desire. Or, the subtle twists of the ego that identify ourselves with our own desires and 'projects.' This attachment Cassian calls a 'dragon's gall' and far worse than the drunkenness of wine or the gluttony of food (Conferences 9.5.1). We must be careful then to 'reject with unwavering strictness of mind those things which cater to our power and which have the appearance of a kind of goodness' (9.6.4). Again, we are in the world of subtle self-delusion, made stronger by the apparent cloak of respectability which those who are involved in altruistic or religious works often wrap themselves up with, the more to bring delusion upon themselves and others. Evagrius of Pontus, another chronicler of the desert sayings, calls it the 'spirit of vainglory' and his pen portrait of its poison is psychologically subtle and still relevant today:

The spirit of vainglory is most subtle and it readily grows up in the souls of those who practice virtue. It leads them to desire to make their struggles known publicly, to hunt after the praise of men. This in turn leads to their illusory healing of women, or to their hearing fancied sounds as the cries of demons... It has men knocking at the door, seeking audiences with them. If the monk does not willingly yield to their request, he is bound and led away. When in this way he is carried aloft by vain hope, the demon vanishes and the monk is left to be tempted by the demon of pride or of sadness (Praktikos 13).

The confessor, then, must be an astute counsellor and psychologist. However, over and above it all, the fathers counsel compassion towards those who struggle. Spiritual guides must never get too haughty and feel they are morally superior to those who come seeking confession. The weakness of the passions can strike anyone at anytime. Cassian gives the telling story of the young man troubled with lust who goes to see the elder who scorns him and tells him he is not worthy of the life of a monk. As he leaves, dejected, to return to the fleshpots of a local town he meets another wiser elder, Abba Apollos. Unlike the first father, Apollos shows compassion and discloses that he himself has to struggle with this demon on a regular basis. As he prays for the young man the demons assail the first old man with the temptations. This old man now 'runs around hither and thither as if he were crazed and drunk' (Conferences 2.13.7) finally setting off on the same route to the local fleshpots. In his 'obscene excitement' Abba Apollos confronts him, asking 
innocently where the former upright father is now heading. Realising that he has been deceiving himself and others the old man falls abash at Apollos' feet. Apollos' final words to the would-be confessor are magnificent:

The Lord let you be wounded by this so that at least in your old age you might learn to be compassionate toward others' infirmities and might be taught by your own example and experience to be considerate with respect to the frailty of the young... Learn to be compassionate to those who struggle and never frighten with bleak despair those who are in trouble or unsettle them with harsh words. Instead encourage them mildly and gently (Conferences 2.8.9).

This tradition of compassion and gentleness remains within the Christian practice of spiritual guidance and confession to today.

Thus, from the monastic and desert traditions the early Church developed a model of confession that was non-liturgical and informationalmore akin, in many respects, to our modern notion of counselling. Without a canonical formula, the advice was given to help individual monks, and later lay people, to find their way back to God through greater wisdom and discernment in their approach to their passions and desires. [Although as Dallen points out (1991: 105) the Eastern tradition would later link the reconciliation and practice of penance to liturgical offices in a communal setting. Celtic monasticism, he suggests, 'seems to have copied the Eastern monastic practice at an early stage of its development before it had advanced beyond simple spiritual direction and been integrated within the monastic liturgy'.] As described by St John Climacus (c.579-c.649) in his Ladder of Ascent, confession, or exomologisis as he terms it, is something that may happen both within the liturgical context of the Church and beyond it. The spiritual father chosen by the monk need not necessarily be a priest (Climacus himself was probably not ordained, see Ware 1982: 38), the overriding metaphor being that the confessor is more like a doctor who heals with 'surgery, bandaging and cauterization' (Ladder of Ascent 5, 130). The patient (the penitent) bears the treatment with trust in the skill of the doctor. Such confession, in contrast to the Western Roman practice we shall discuss in the next chapter, can occur on a regular basis and in many respects, as we shall see later, has more in common with contemporary understandings of counselling than the Western notion of exculpation of sins at infrequent periods. For as Metropolitan Kallistos Ware points out (Ware: 1982: 38), the monk not only confesses sins but also thoughts and logismoi, whether they are good, bad or neutral. Ware stresses that throughout 'John (Climacus) employs by preference imagery that is therapeutic rather than juridical. Confession does not merely bestow absolution from guilt, understood in a formal or legalistic fashion, but on a deeper, more organic level it 
confers healing and restoration in wholeness. Sin is disease, to go to confession is to enter the hospital' (Ware 1982: 39).

It is my contention here that it is precisely this psychological verisimilitude which ultimately proved so helpful in spreading this 'desert' practice of confession, via the Celtic church, throughout the Western church, ultimately triumphing over the Southern European practices of public, one-off penance we explored earlier. It is to this process that we turn next.

\section{5-The Celts Triumphant}

Catholic confession as we know it today was invented 800 years ago, the year 1215 to be precise. In that year, the church fathers of the West met at the church of St John Lateran in Rome and decided that the practice of individual confession as had crept down to Southern Europe from the Celtic fringes of the North and West should be adopted by the Western church. In the centuries and decades preceeding the Council this new form of confession had taken hold of the Latin West-individual auricular confession to a priest who would then absolve the sins committed. This practice, so familiar to us today, would have been unknown to, amongst others, St Augustine who would have been more acquainted with the notion of general absolution of sins in public ceremonies described previously.

From the Celts then, who would spread their system throughout Europe as they practised their missionary zeal, the notion of individual spiritual direction allied to a tariff for individual sins committed began to emerge and take the place of the older Roman communal and liturgically based absolution. What cannot be found in the Celtic system, however, is a notion of a ritual of absolution allowing the penitent to be restored to the bosom of the flock of Christ. Thus, by the time the Church fathers met in 1215 to codify various ecclesiastical practices they were faced with a situation where the Celtic-monastic form of individual penance, confession and spiritual direction had become popular in most of the domains of the Western church whilst the old form of public liturgical penance and confession had become increasingly infrequent. Their work at the beginning of the century would be supplemented by that of the later scholastic theologians such as St Thomas Aquinas, Duns Scotus, and the Victorines who all discussed the nature and sacramentality of the forms of confession then in circulation within the Church, their arguments often focussing on the question of where the sacramentality of the process resided. Scotus had argued that the uttering of the words 'te absolvo' was essential for the sacramental validity of absolution whilst Abelard suggested it lay in contrition. Thomas in the Summa Theologicae distinguishes between penance as a virtue and penance as a sacrament. For him the parts of the sacrament were the penitent's acts (contrition, confession and satisfaction) thus creating for him a fusion in the sacrament be- 
tween the personal and the public taking his definition of 'sacrament' from St Gregory the Great: 'a sacrament consists in a certain ceremony in which the action is so performed that we take it to signify the sanctity it bestows' (ST: Qu. 84, art. 1). Therefore, in confession, 'the ceremony is so done that something holy is signified'. Two other aspects of Thomas' analysis of confession in the Summa Theologicae are also worth noting. First, reflecting the now widespread use of Celtic forms of penance, he argues that confession is not a one-off event but something that can be repeated throughout life (ST: Qu. 84, art. 10). Secondly, as he stresses the sacramentality of the act he is at pains to distinguish 'two types of confession of sins': 'one is interior and is made to God. The other is outward confession of sins which is made to a priest' (ST: Qu. 68, art. 6). This split between sacramental and nonsacramental forms of confession will be one that will have long reaching consequences for the Western notion of confession and the self in general, as we shall see shortly.

Thus, the culmination of all these medieval developments can be seen in Canon 21 of the Fourth Lateran Council which stated:

All the faithful of both sexes shall after they have reached the age of discretion faithfully confess all their sins at least once a year to their own (parish) priest and perform to the best of their ability the penance imposed, receiving reverently at least at Easter the sacrament of the Eucharist, unless perchance at the advice of their own priest they may for a good reason abstain for a time from its reception; otherwise they shall be cut off from the Church (excommunicated) during life and deprived of Christian burial in death. Wherefore, let this salutary decree be published frequently in the churches, that no one may find in the plea of ignorance a shadow of excuse. But if anyone for a good reason should wish to confess his sins to another priest, let him first seek and obtain permission from his own (parish) priest, since otherwise he (the other priest) cannot loose or bind him.

The somewhat legalistic formula, stressing the need for annual confession for those who had 'reached the age of discretion' also paid homage to the older Celtic-monastic tradition of spiritual guidance by suggesting further that:

The priest be discreet and cautious that he may pour wine and oil into the wounds of the one injured after the manner of a skilful physician, carefully inquiring into the circumstances of the sinner and the sin, from the nature of which he may understand what kind of advice to give and what remedy to apply, making use of different experiments to heal the sick one. But let him exercise the greatest precaution that he does not in any degree by word, sign, or any other manner make known the sinner, but should he need more prudent counsel, let him seek it cautiously without any mention of the person. He who dares to reveal a sin confided to him in the tribunal of penance, we decree that he be not 
only deposed from the sacerdotal office but also relegated to a monastery of strict observance to do penance for the remainder of his life.

The wound and physician metaphors are striking. The monastic tradition, as we have seen, had long emphasised this aspect of confession. The Church Fathers at the Lateran Council added to this the formulas of sacramentality which will take confession into the next stage of its development. However, as this ecclesiastical form of confession developed there was also a concomitant secular development to which we turn next.

\section{The Confessional Shift}

The confessional shift of 1215 cannot be underestimated for at this point two rivers meet. In Dallen's words: 'the two ancient roles of spiritual counsellor and community official were thus combined in the person of the priest-confessor' (Dallen 1991: 142). As the role of the priest and authority figure increased that of the lay person and counsellor declined (although Aquinas still admits in the 13th century that sins can be confessed to a lay person-even mortal sins in extremis). Modern confession, as it emerged in the 13th century and focussed on the priest-confessor, was one where both confession and absolution of sins were combined in the service of the sacrament. Although this simplified things from the canonical point of view from a psychological perspective it had the effect of obscuring some key aspects of the confessional.

In conclusion, I would like to suggest that the practice of confession contains two elements: an aspect that allows psychological healing, equivalent in many respects to the type of healing described by Sigmund Freud and Carl Jung and found today in a modern counselling or psychotherapeutic setting (see, for example, Freud 1926 / 1959 and Jung 1933 / 1990); and secondly, that it contains a 'window on to the transcendent' as described by writers such as St Augustine in his Confessions. Once the psychological practice of confession became wedded to the church's ability to bestow absolution of sins from the 13th century onwards these two elements merged together, which is to say that the element of confession that allows the healing of the soul became yoked to the canonical requirements of the sacrament.

Once the Western church had codified its reactions to a particular understanding of confession, penance and absolution in 1215 we can observe other movements growing in the Western psyche that seek to find this confessional aspect outside the church. We could even go so far as to suggest that this outgrowth will eventually find its way into what we may today call the 'psychological' healing arts. However, to trace that genealogy would be beyond the scope of this article.

\section{Bibliography}


Aquinas T (1874) Summa Theologiae. Edited by Gilbey T. London: Eyre and Spottiswoode: Baptism and Confirmation. Volume 57, Trans. Cunningham $\mathrm{J}$.

Aquinas T (1966) Penance. Volume 60, trans. O’Brien T.

Athanasius (1998) The Life of St Anthony. Trans. White C. London: Penguin.

Augustine of Hippo (1992) Confessions. Trans. O’Donnell J. Oxford: Clarendon (3 volumes).

Cassian J (1997) The Conferences. Edited by Ramsey B. New York, NY: Newman Press.

Conférences (1955-59) Edited by Pichery E. Sources Chrétiennes 42, 54, 64. Paris: Cerf.

Climacus J (1982) The Ladder of Divine Ascent. Trans. C. Luibheid and N. Russell. Mahwah, NJ: Paulist.

Dallen J (1991) The Reconciling Community: The Rite of Penance. Collegeville, MT: The Liturgical Press.

Evagrius of Pontus (1981) Evagrius Ponticus Praktikos-The Chapters on Prayer. Cistercian Studies No. 4. Trans. Bamberger J. Kalamazoo, MI: Cistercian.

Évagre le Pontique, Traité Pratique ou Le Moine. Sources Chrétiennes 170 and 171, edited by Guillaumont A, Guillaumont C. Paris: Cerf.

Freud S (1925/59) Standard Edition of the Complete Psychological Works of Sigmund Freud. Trans. Strachey J. London: The Hogarth Press, including: The Question of Lay Analysis. Volume 20.

Jung C (1933/1990) Modern Man in Search of a Soul. Trans. Dell W and Baynes H. London: Routledge.

Rahner K (1969) Sacramentum Mundi: An Encyclopedia of Theology, edited with Ernst C, Smyth K. London: Burns and Oates.

Rahner K (1983) Theological Investigations, Volume XV, Penance in the Early Church. Trans. Swain L. London: Darton, Longman and Todd.

Tertullian (1959) On Penitence in Tertullian: Treatises on Penance (De Paenitentia) in Ancient Christian Writers. Trans. le Saint W. London: Longmans. Volume 28.

Tertullien (1984) Tertullien: La Pénitence. In Sources Chrétiennes 316, Trans. Munier C. Paris: Cerf.

Ward B, ed (1984) The Sayings of the Desert Fathers: the Alphabetical Collection. Kalamazoo, MI: Cistercian Publications.

Ware K (1982) Introduction to The Ladder of Divine Ascent. Trans. Luibheid C, Russell N. Mahwah, NJ: Paulist.

*** (1990) Decrees of the Ecumenical Councils. Edited by Tanner E. Cambridge: Cambridge University Press.

*** (1997) The Complete Dead Sea Scrolls in English. Edited by Vermes G. London: Allen Lane. 
*** (2007) Scripture Quotations from the New Revised Standard Version. London: Harper, with modifications as necessary. 